Tropical Journal of Pharmaceutical Research, August 2009; 8 (4): 331-336

(C) Pharmacotherapy Group,

Faculty of Pharmacy, University of Benin,

Benin City, 300001 Nigeria.

All rights reserved.

Research Article

Available online at http://www.tjpr.org

\title{
Antipyretic and Analgesic Effects of the Aqueous Extract of the Fruit Pulp of Hunteria umbellata K Schum (Apocynaceae)
}

\section{Ighodaro Igbe ${ }^{1^{\star}}$, Raymond I Ozolua ${ }^{1}$, Steve 0 Okpo ${ }^{1}$ and Osahon Obasuyi ${ }^{2}$}

${ }^{1}$ Departments of Pharmacology \& Toxicology and ${ }^{2}$ Pharmaceutical Microbiology, Faculty of Pharmacy, University of Benin, Benin City 300001, Nigeria

\begin{abstract}
Purpose: The aqueous fruit pulp extract of Hunteria umbellata K. Schum is used traditionally for the treatment of various fevers. The purpose of this study was to evaluate the extract for antipyretic and analgesic activity, and determine its probable mechanism of action.

Methods: Pyrexia was induced in rabbits by intravenous injection of $10^{5} \mathrm{CFU}$ of E. coli/kg. Rectal temperature was monitored at 30, 60, and $90 \mathrm{~min}$ post-administration of 250 and $500 \mathrm{mg} / \mathrm{kg}$ of the extract. The analgesic effect of the extract was evaluated using acetic acid-induced mouse writhing test. The extract was tested for antimicrobial activity against Staphylococcus aureus, Klebsiella pnuemoniae, Escherichia coli, and Psuedomonas aeruginosa using agar diffusion method. Phytochemical screening of the plant extract was also carried out.

Results: Phytochemical screening revealed the presence of simple sugars, saponins, flavonoids, alkaloids and steroidal compounds. The extract $(250,500 \mathrm{mg} / \mathrm{kg})$ and aspirin produced comparable antipyretic effects up to $60 \mathrm{~min}$. The extract did not inhibit the growth of the microorganisms but significantly reduced the number of writhes in mice at 250 and $500 \mathrm{mg} / \mathrm{kg}$ with results comparable to ASA.

Conclusion: The extract possesses antipyretic and analgesic activities which validate its use in the treatment of pains and fevers.
\end{abstract}

Keywords: Hunteria umbellata; Anti-pyrexic; Analgesic; Antibacterial effect. 


\section{INTRODUCTION}

Due to poor hygiene practices and malnutrition, children in developing countries frequently suffer from various forms of infections which present as fevers ${ }^{1}$. These fevers are often accompanied by aches and pains which all lead to morbidity and mortality. Herbal medicines are often used as remedies in these conditions since as a result of poverty orthodox medicines may be unaffordable ${ }^{2}$. It is a well known fact that herbal medicines may be sources of substances with better therapeutic potentials than some currently used orthodox medicines $^{3}$.

Hunteria umbellata K. Schum (Apocynaceae) is a small tree of about $15-22 \mathrm{~m}$ in height with a dense evergreen crown ${ }^{4}$. It is found in rain forest zone of the southern part of Nigeria where it bears such local names as Osu (Edo), erin (Yoruba) and nkpokiri (Ibo) ${ }^{5}$. It is also found in Ubongi-Shari in Ghana and the rain forest regions of Cameroon and Gabon. The leaves have been described as broad, abruptly acuminate and broadly lineate ${ }^{5,6}$. The fruit is about $5-25 \mathrm{~cm}$ and consists of two separate globose mericaps 3$6 \mathrm{~cm}$ long, yellow, smooth, $8-25$ seeded embedded in a gelatinous pulp ${ }^{6}$.

Various parts of the plant have been used in herbal medicine for the treatment of Diabetes $^{7}$, peptic ulcers, piles, yaws, dysmenorrhoea, fever, infertility ${ }^{8}$, helminthic infection $^{9}$, and as an oxytocic ${ }^{10}$. Members of the genus, Hunteria, have been widely employed in traditional herbal medicine. For example, crude alkaloids extracted from the stem bark of Hunteria zeylanica inhibited acute inflammation in experimental animals. Antinociceptive and antipyretic effects of alkaloids extracted from the stem bark of $\mathrm{H}$. zeylanica have also been reported ${ }^{11}$

Although the fruit pulp of $H$. umbellata has been used traditionally in treatment of various fevers by boiling with water and subsequent drinking of the extract, there is no scientific evidence to support this therapeutic use. Since bacteria and other microorganisms cause fevers, it is possible that the usefulness of this extract is dependent on antimicrobial activity. However, many aspirinlike drugs used in the treatment of dysmenorrhoea do not possess antimicrobial activity. We have, therefore, undertaken the present study in order to evaluate the antipyretic and analgesic activity of the aqueous fruit pulp extract of this plant and to determine whether this is occurs via antibacterial activity or mechanisms related to analgesia.

\section{EXPERIMENTAL}

\section{Plant material}

The ripe fruits of $H$. umbellata were collected from bushes around Benin City, Nigeria in the month of September. The plant was identified by the staff of the Department of Pharmacognosy, University of Benin, Benin City, Nigeria and was later authenticated at the Forest Research Institute of Nigeria where a voucher specimen with number $\mathrm{FHI}$ 107678 has been deposited.

\section{Extraction}

The seeds were first removed from the ripe fruits and the fruit pulps were chopped into pieces and sun-dried to a constant weight over a 14-day period. The dried material was then powdered using a mechanical grinder. The powdered material $(400 \mathrm{~g})$ was boiled with $1.500 \mathrm{ml}$ of distilled water for $30 \mathrm{~min}$ to obtain the aqueous extract. The extract was filtered, concentrated under pressure in a rotar vapor at $68{ }^{\circ} \mathrm{C}$ and dried in an oven set at $40{ }^{\circ} \mathrm{C}$ for $48 \mathrm{~h}$ (yield: $21 \%$ ). The dried aqueous extract was preserved in clean glass containers at $4{ }^{\circ} \mathrm{C}$ in a refrigerator until use.

\section{Phytochemical screening}

The aqueous extract of $H$. umbellata was screened for various chemical constituents (simple sugars, tannins, alkaloids, cardiac 
glycosides, flavonoids, steroidal compounds, saponins, anthracene derivatives and simple sugars) using established methods ${ }^{12,13}$.

\section{Animals}

The experiments were performed using New Zealand rabbits of both sexes weighing between $1.1-1.5 \mathrm{~kg}$ and adult male mice weighing between $20-30 \mathrm{~g}$. The rabbits were obtained from Aduwawa animal farm, Ikpoba Hill, Benin City, Nigeria and were allowed two weeks of acclimatization. The mice were bred locally at the animal house of the Department of Pharmacology \& Toxicology, University of Benin. The rabbits were fed on growers' mash (Bendel Feeds and Flour Mill, Nigeria Ltd) while the mice were fed on standard rodent cubes (Ladokun Feeds Plc, Nigeria). Feeds and water were freely available to all animals throughout the experiments. The animals were exposed to natural lighting conditions and handled according to standard protocols for the use of laboratory animals approved by the Faculty of Pharmacy Committee on the Use of Experimental Animals.

\section{Antipyretic experiment}

Antipyretic activity was determined by a modified method previously described ${ }^{14}$. Briefly, basal rectal temperatures of the rabbits were taken using a probe thermometer (model Panlab-0331). Thereafter, pyrexia was induced by injecting $10^{5} \mathrm{CFU}$ of $E$. coli/kg into the marginal ear vein of each rabbit. The rectal temperature of the rabbits was again taken $1 \mathrm{~h}$ after induction of pyrexia and animals having temperature between 38.7 and $39.7{ }^{\circ} \mathrm{C}$ (representing significant temperature increase from basal values of $37.41 \pm 0.58$ ${ }^{\circ} \mathrm{C}$ ) were regarded as hyperthermic and were randomly assigned to four groups $(A-D)$ of four rabbits each. Doses of 250 and 500 $\mathrm{mg} / \mathrm{kg}$ of extract dissolved in distilled water were administered orally to the rabbits in groups A and B respectively, using an orogastric tube. A dose of $100 \mathrm{mg} / \mathrm{kg}$ of acetylsalicylic acid (ASA) constituted in $10 \%$ ethanol was administered orally to animals in group $C$ which served as positive control. The rabbits in group $D$ received $2 \mathrm{ml} / \mathrm{kg}$ of the vehicle for ASA (10\% ethanol) orally and served as negative control. The post-drug treatment rectal temperature of each rabbit was recorded at time points 30,60 , and 90 min. The differences in temperature before and after the administration of the extract or ASA were recorded as $\mathrm{dT}$.

\section{Analgesic experiment}

The analgesic effect of extract was evaluated by using the acetic acid-induced mouse writhing test ${ }^{15}$. Adult mice were randomly allotted to four groups $(A-D)$ of 5 mice each. The extract was administered orally at doses of 250 and $500 \mathrm{mg} / \mathrm{kg}$ to groups A and B respectively. Mice in groups $C$ were given $100 \mathrm{mg} / \mathrm{kg}$ of ASA in $10 \%$ ethanol orally while group D received $2 \mathrm{ml} / \mathrm{kg}$ of $10 \%$ ethanol orally. After $1 \mathrm{~h}$ of treatment, all animals were administered $10 \mathrm{ml} / \mathrm{kg}$ of 0.6 $\% \mathrm{v} / \mathrm{v}$ acetic acid in normal saline intraperitoneally. The number of writhes by each mouse was counted immediately after acetic acid administration at intervals of $5 \mathrm{~min}$ for a period of $30 \mathrm{~min}$.

\section{Antibacterial experiment}

Bacteria (Staphylococcus aureus, Escherichia coli, Klebsiella pnuemoniae and Pseudomonas aeruginosa) were obtained from the stock culture of the Department of Pharmaceutical Microbiology, Faculty of Pharmacy, University of Benin. Standard inocula of the organisms were prepared by growing the pure isolates in nutrient agar for $24 \mathrm{~h}$. Using a sterile wire loop, a smear of the agar was inoculated in nutrient broth for each organism and incubated at $37^{\circ} \mathrm{C}$ for 18 h. Sterile plates of $20 \mathrm{ml}$ molten agar were seeded with $0.2 \mathrm{ml}$ of the well-shaken nutrient broth of each organism. Each plate of molten agar was rotated slowly to ensure uniform distribution of the bacterium and thereafter left to solidify. 
The sensitivity of the organisms to the aqueous extract of $H$. umbellata was evaluated by the cup-plate agar diffusion method $^{16}$. Wells of $8 \mathrm{~mm}$ diameter were made in each agar plate using a sterile cork borer.
A quantity $(0.25 \mathrm{ml})$ of different concentrations of the extract $(7.5,12.5,25$, 50 and $75 \% \mathrm{w} / \mathrm{v}$ ) dissolved in distilled water, was then placed in each well. Each volume of distilled water was assayed as control. Ciprofloxacin $(5 \mu \mathrm{g} / \mathrm{ml})$ was used as the standard antimicrobial agent and tested along with the extract. The plates were allowed to stand for $30 \mathrm{~min}$ at room temperature to allow proper diffusion of extract after which they were incubated at $37{ }^{\circ} \mathrm{C}$ for $24 \mathrm{~h}$. The diameter of the zone of inhibition was measured and recorded for each concentration and for each organism.

\section{Statistical analysis}

Results are presented as the mean \pm standard error of the mean (SEM) and $n$ represents the number of animals per group in which antipyretic and analgesic activities were determined. Data comparisons between treatment groups were done by use of oneway ANOVA followed by Tukey-Kramer post hoc test. Values were considered statistically significant at $p<0.05$.

\section{RESULTS}

Phytochemical screening revealed the presence of simple sugars, saponins, flavonoids, alkaloids and steroidal compounds. Figure 1 shows that compared to vehicle-treated rabbits, doses of 250 and $500 \mathrm{mg} / \mathrm{kg}$ of extract, and $100 \mathrm{mg} / \mathrm{kg}$ of ASA, significantly $(p<0.05)$ decreased the rectal temperature of the rabbits 30 and $60 \mathrm{~min}$ after treatment. Only $100 \mathrm{mg} / \mathrm{kg}$ of ASA significantly $(p<0.01)$ decreased the rectal temperature at 90 min post-treatment. The rectal temperature of rabbits treated with only the vehicle increased consistently from basal value over the period of measurement
Regardless of the incubated organism, the various concentrations of extract did not produce zones of inhibition in agar plates.

The extract $(250,500 \mathrm{mg} / \mathrm{kg})$ produced the same pattern of analgesia in the acetic acidinduced mouse writhing test as $100 \mathrm{mg} / \mathrm{kg}$ of ASA (Figure 2) The number of writhes by mice treated with either extract or ASA was significantly $(p<0.01, p<0.001)$ reduced when compared with the number of writhes by saline-treated mice at any time point within the 30 min of experiment.

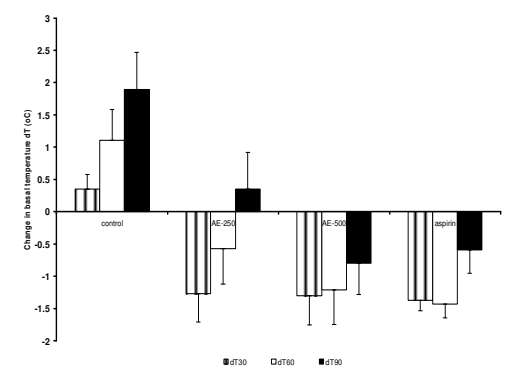

Figure 1: Changes in basal rectal temperature (dT) measured at 30, 60 and $90 \mathrm{~min}$ after administration of aqueous extract (AE) of $H$. umbellata or acetylsalicylic acid (ASA). ${ }^{*} p<0.05$ compared to same time points with vehicle. $n=4$ per group.

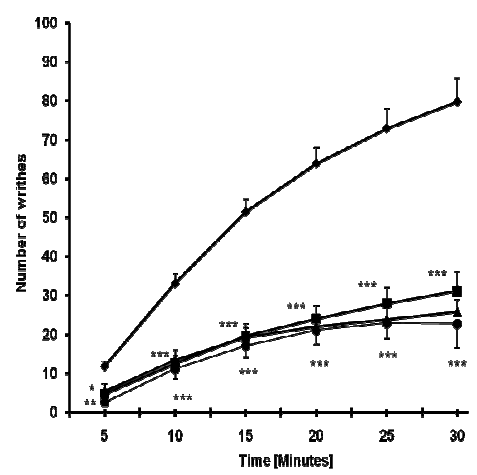

Figure 2: Effect of aqueous extract of $H$. umbellata on acetic acid-induced mouse writhing. ${ }^{*} p<0.05,{ }^{* *} p<0.01,{ }^{* * *} p<0.001$ as compared to the corresponding time point for control. $n=5$. Control (४), H. umbellata $250 \mathrm{mg} / \mathrm{kg}(\mathbf{\bullet})$, H. umbellata 500 $\mathrm{mg} / \mathrm{kg}(\mathbf{\Delta})$, ASA (•). 


\section{DISCUSSION}

Bacteria cause fever because of the endotoxin lipopolysaccharide found in their cell wall. The subsequent elaboration of interleukin- 1 and tumour necrosis factor- $\alpha$ is believed to initiate the synthesis and release of the fever-causing autacoid prostaglandin $E_{2}\left(P E_{2}\right)$ by the endothelium and pericytes of brain capillaries ${ }^{17}$. Hence antibacterial agents eventually abolish fever. The failure of various concentrations of the extract (up to $75 \% \mathrm{w} / \mathrm{v}$ ) to cause inhibition of clinical isolates of $S$. aureus, E. coli, K. pnuemoniae and $P$. aeruginosa when compared to the inhibitory effect of the standard drug, Ciprofloxacin $5 \mu \mathrm{g} / \mathrm{ml}$ indicates that extract's antipyretic activity is not likely to depend on antibacterial activity. The fact that the extract reduced fever of unknown cause suggests that it may act through mechanisms not related to antimicrobial activity.

The acetic acid-induced mouse writhing test has been used extensively to qualify analgesic agents that have peripheral analgesic action ${ }^{18}$. This peripheral action is known to be due to the inhibition of painmediating autacoids such as prostaglandins. The comparable antipyretic and analgesic efficacy of the extract and ASA in the present study is indicative of similarity in mechanism of action. ASA, like other non-steroidal antiinflammatory/analgesic agents, acts by the inhibition of the synthesis of prostaglandins that are responsible for pain and pyrexia ${ }^{19}$. The analgesic property of extract which may explain its use in traditional medicine in the treatment of dysmenorrhoea has to the best of our knowledge not been reported elsewhere. With respect to antipyretic action, there is no qualitative difference between the two doses of extract tested, $30 \mathrm{~min}$ after treatment.

\section{CONCLUSION}

The results demonstrate that $H$. umbellata possesses an antipyretic effect that is independent of antibacterial activity. Since it produces peripheral analgesic properties, inhibition of some autacoids may explain its antipyretic action. These pieces of evidence accentuate its use in the treatment of fevers of unknown cause in traditional medicine in southern Nigeria.

\section{ACKNOWLEDGEMENT}

This study was supported by a postgraduate grant to Ighodaro Igbe by the Steven Oluwole Awokoya Foundation for Science Education, Nigeria. The authors are grateful to Mr John Abanum and Mrs Celina Etamesor for taking care of the animals.

\section{REFERENCES}

1. Franco-Paredes $C$, Jones $D$, Rodriguez-Morales AJ, Santos-Preciado Jl. Commentary: Improving the health of neglected populations in Latin America. BMC Public Health, 2007; 7: 7-11

2. Soucat A, Levy-Bruhl D, De Bethune X, Gbedonou $P$, Lamarque JP, Bangoura $O$, Camara $O$, Gandaho T, Ortiz C, Kaddar M, Knippenberg R. Affordability, cost-effectiveness and efficiency of primary health care: the Bamako initiative experience in Benin and Guinea. Int $J$ Health Plan Mgt, 1997; 12: S81-S108.

3. Wang Y., Wang $X$, Cheng Y. A computational approach to botanical drug design by modeling quantitative composition-activity relationship. Chem Biol Drug Design, 2006; 68: 166- 172.

4. Oliver B. Medicinal Plants in tropical West Africa. Cambridge University Press, Cambridge, 1986, pp 60-62

5. Boone MJ. Hunteria umbellata (K.Schum.) Hallier $f$. In: Schmelzer, G.H. \& Gurib-Fakim, A. (Editors). Prota 11: Medicinal plants/Plantes médicinales 2006. [CD-Rom]. PROTA, Wageningen, Netherlands.

6. Keay RWJ, Onochie CFA, Stanfield DP. Nigerian Trees. Vol. II. Federal Department of Forest Research, Ibadan, Nigeria, 1964, pp 378-379

7. Raman A, Mallam V. Enhanced in vitro activity of glucokinase enzyme in the presence of Hunteria umbellata seeds, a traditional Nigerian treatment for diabetes. J Pharm Pharmacol, 1994; 46: 1046.

8. Elujoba $A A$. Female infertility in the Lands of traditional birth attendants in South-Western Nigeria. Fitoterapia, 1995; 66: 239-248.

9. Oluwemimo $A$, Usifoh $C O$. The antihelminthic activity of Hunteria umbellata K. Schum. (Fam. Apocynaceae) extracts. Pak J Pharm Sci Ind Res, 2001; 44: 286- 290. 
10. Falodun A, Nworgu ZAM, Ikponmwosa MO. Phytochemical components of Hunteria umbellata (K. Schum) and its effect on isolated non-pregnant rat uterus in oestrus. Pak $J$ Pharm Sci, 2006; 19: 256-258.

11. Reanmongkol W, Matsumoto $K$, Watanabe $H$, Subhadhirasakul S, Sakai S.

Antinociceptive and antipyretic effects of alkaloids extracted from the stem bark of Hunteria zeylanica. Biol Pharm Bull, 1994; 17:13451350.

12. Evans $W$ C: Trease and Evans Pharmacognosy,13th ed. Bailliere Tindall, London 1989. pp. 388546

13. Harborne JB. Phytochemical methods. A guide to modern techniques of plant analysis, 2nd ed.Chapman and Hall, New York 1983, pp 5968.

14. Backhouse $N$, Delporte $C$, Negrete $R$, Salinas $P$, Pinto A, Aravena $S$, Cassels BK. Antiinflammatory and antipyretic activities of Cuscuta chilensis, Cestrum parqui and Psorolea glandulosa. International Journal of Pharmacognosy, 1996; 34: 53-57

15. Adeyemi OO, Okpo SO, Okaka O. The analgesic effect of the methanolic extract of Acanthus montanus. J Ethnopharmacol, 2004; 90: 4548.

16. Ebi GC, Ofoefule SI. Phytochemical and antimicrobial screening of extractives from Pterocarpus osun elder stems showed significant activities due to different classes of new isolated constituents. Fitoterapia, 2000; 71: 433-435.

17. Steiner $A A$, Ivanov $A l$, Serrats J, Hosokawa $H$, Phayre AN, Robbins JR, Roberts JL, Kobayashi S, Matsumura K, Sawchenko PE, Romanovsky $A A$. Cellular and molecular bases of the initiation of fever. PLoS Biol, 2006; 4: e284.

18. Neves $S A$, Freitas $A L$, Sousa BW, Rocha $M L$, Correia MV, Sampaio DA, Viana GS. Antinociceptive properties in mice of lecitin isolated from the marine alga Amansia multifida Lamouroux. Braz J. Med and Biol Research, 2007; 40: 127-134.

19. Simmons DL, Botting RM, Hla T. Cyclooxygenase isozymes: the biology of prostaglandin synthesis and inhibition. Pharmacol Rev, 2004; 56: $387-437$. 